\title{
サルモネラによる急性化膿性甲状腺炎例
}

\author{
盛實 勲 ${ }^{1)} \cdot$ 有友 宏 ${ }^{2)} \cdot$ 浅井 真紀 ${ }^{3)} \cdot$ 田口 亜紀 ${ }^{1)}$
}

\section{Salmonella and Acute Suppurative Thyroiditis}

\author{
Isao Morizane and Aki Taguchi \\ (Ehime University School of Medicine) \\ Hiroshi Aritomo \\ (Matsuyama Red Cross Hospital) \\ Masanori Asai \\ (Ehime Prefectural Imabari Hospital)
}

\begin{abstract}
Acute suppurative thyroiditis due to salmonella is an extremely rare condition because the thyroid gland is totally encapsulated and has a high local iodide content, with a rich lymphatic and vascular supply. We report a case of acute suppurative thyroiditis in a 50 -year-old woman. She presented with a painful swelling in the left neck. She had neither symptom nor history of gastroenteritis. Ultrasound examination of the thyroid suggested an abscess of the inferior pole of the left thyroid lobe. Purulent fluid obtained by fine needle puncture grew Salmonella Anatum. The abscess got worse despite the intravenous administration of antibiotics, and surgical drainage was performed. No evidence of piriform sinus fistula was found in barium swallowing examinations two and five months after surgery. Although the route of infection remained unclear, a hematogenous route seemed to be the most likely.
\end{abstract}

Key words : salmonella, acute suppurative thyroiditis, piriform sinus fistula, hematogenous route

はじめに

急性化膿性甲状腺炎は下咽頭梨状陥凹瘦が主たる感染 ルートであり122), リンパ行性, 周囲組織からの直接的波 及, 甲状舌管の遺残, 外傷や血行性など3) の他の感染経 路の頻度はきわめて低い．起炎菌としては口腔や咽頭の 常在菌であるStreptococcus, Staphylococcus, Klebsiella な ぞが多い4)。今回，われわれは下咽頭梨状陥凹瘦が証明 されず血行性感染と考えられた，サルモネラによる急性 化膿性甲状腺炎の 1 例を経験したので文献的考察を加え 報告する。

\begin{abstract}
症例
症例 : 50 歳, 女性.

主訴：左前頸部腫脹, 疼痛.

現病歴: 1999 年 5 月 15 日より感冒様症状があり, 18 日から左前頸部腫脹と疼痛も伴ってきたため当院内科を 受診した. その際, 血液検査にて白血球数 $11400 / \mathrm{mm}^{3}$, $\mathrm{CRP} 0.61 \mathrm{mg} / \mathrm{dl}$ と急性炎症の像を示した. 甲状腺機能は 正常範囲でサイログロブリンの軽度上昇を認めるのみ であった (表 1). 亜急性甲状腺炎としてプレドニゾロン $20 \mathrm{mg} /$ 日を投与したが, 頸部腫脹は増大した. 5 月 21 日， 超音波検查で膿瘍が疑われたため（図 1), プレドニゾロ
\end{abstract}

1）愛媛大学耳鼻咽喉科学教室

2）松山赤十字病院耳鼻咽喉科

3）愛媛県立今治病院耳鼻咽喉科 
表 1 血液検查成績

\begin{tabular}{|c|c|c|c|c|c|c|}
\hline & & 5 月 18 日 & 5 月 24 日 & 6 月 7 日 & 6 月 17 日 & 7月 1 日 \\
\hline 白血球数 & $\left(/ \mathrm{mm}^{3}\right)$ & 11400 & 10200 & 3700 & 3800 & \\
\hline CRP & $(\mathrm{mg} / \mathrm{dl})$ & 0.61 & 22.00 & 1.78 & $<0.15$ & \\
\hline TSH & $(0.4 \sim 3.7 \mu \mathrm{IU} / \mathrm{ml})$ & 0.5 & & $<0.1$ & $<0.1$ & 3.3 \\
\hline free T3 & $(2.2 \sim 4.1 \mathrm{pg} / \mathrm{ml})$ & 2.9 & & 4.5 & 2.3 & 2.4 \\
\hline free $\mathrm{T} 4$ & $(0.8 \sim 1.7 \mathrm{ng} / \mathrm{d} 1)$ & 1.6 & & 2.3 & 1 & 0.9 \\
\hline サイログロブリン & $(\leqq 30 \mathrm{ng} / \mathrm{ml})$ & 60 & & & & \\
\hline サイロイドテスト & & & & - & & \\
\hline マイクロゾームテスト & & & & - & & \\
\hline
\end{tabular}

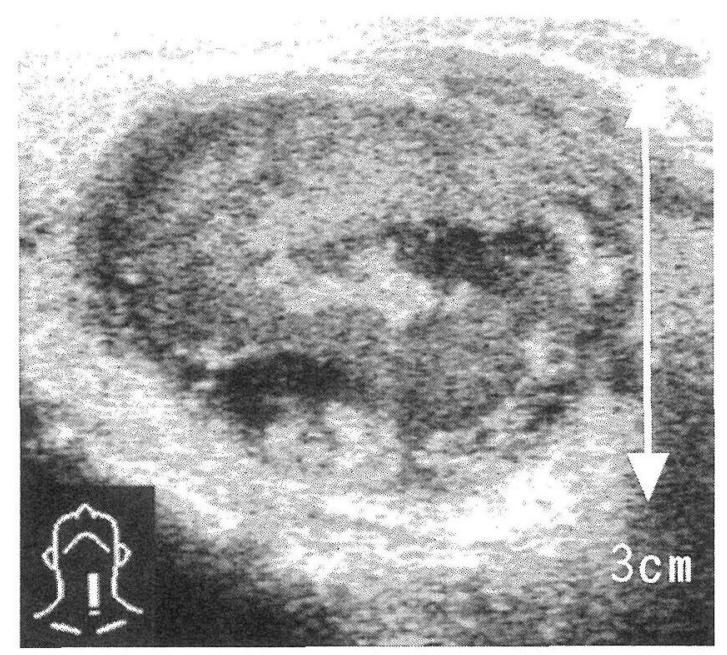

図 1 頸部超音波検查

甲状腺左葉下極に腫瘤状陰影を認め，内部は不均一で低 エコーレベルと高エコーレベルとが混在しており膿瘍が 疑われた。

ンは中止，セフォリス (CFSL) $2 \mathrm{~g} /$ 日の点滴投与を開始 した（図 2)。しかし，その後も頸部腫脹が改善しないた め 5 月 24 日当科紹介受診となった。経過を通じて下痢な ぞの消化器症状はなかった。

既往歴：特記すべきことなし。

家族歴：特記すべきことなし。

現症：左前頸部に軽度の発赤を伴うびまん性腫脹と強 い圧痛を認めた。喉頭ファイバースコピーでは左の披裂 部，仮声帯，声帯および声門下に浮腫を認め, 左の梨状 樎凹には唾液貯留を認めた（図 3 a）。左声帯の可動性は 不良で，発声時の声門閉鎖は不十分であった（図 $3 \mathrm{~b}$ ).

血液検查成績 (5月 24 日) : 白血球数 $10200 / \mathrm{mm}^{3}$, CRP
$22.00 \mathrm{mg} / \mathrm{dl}$ と強い炎症反応を認めた（表 1 ）。

臨床経過： 5 月 24 日血液検查で軽度の肝障害を認めた ため，パニペネム (PAPM) 1g/日，クリンダマイシン (CLDM) $0.6 \mathrm{~g}$ /日に変更した (図 2).5 月 25 日造影 CT 検查を施行したところ，甲状腺左葉下極に辺縁はやや不 整で内部は均一な低吸収を示す腫瘤状陰影を認め，気管 は著明に右方に圧排されていた（図 $4 \mathrm{a}$ )。腫瘤は造影効 果がそしく，周囲のリンパ節腫脹も認めなかった（図 4 a）。腫瘤を穿刺したところ，膿血性で粘稠な貯留液を $8 \mathrm{ml}$ 吸引した。貯留液の細菌検查で Salmonella Anatum が同定され，細胞診では多数の好中球を認めた．以上よ りサルモネラによる急性化膿性甲状腺炎と診断した。な お，経過を通じて血液，便，尿，口腔からはサルモネラ は同定されなかった。

穿刺排膿後，すみやかに喉頭浮腫は消退し，前頸部腫 脹も改善したため保存的治療を続けた。しかし 5 月 31 日 には再び頸部腫脹が増大し，造影 CT 検査を施行したと ころ膿瘍腔の拡大を認めた (図 $4 \mathrm{~b}) .6$ 月 1 日には再び喉 頭浮腫が出現したため, 6 月 4 日切開排膿を行った (図 2 ).

切開排膿手術は全身麻酔下に行った。前頸部の最も腫 脹の強い部位に横切開を加え甲状腺を露出した。甲状腺 の左葉下極に黒褐色の膨隆した膿瘍を認め, 超音波振動 メスを用い切開したところ大量の膿が流出した。膿瘍腔 の洗浄を行った後，止血を確認し，創部は開放創として 手術を終了した。

術後は抗生物質を菌検査で感受性のあったセフォタキ シム (CTX) $3 \mathrm{~g} /$ 日，クリンダマイシン (CLDM) $1.8 \mathrm{~g} /$ 日 に変更し（図 2)，頻回に創洗浄を行った。6月７日には 白血球数 $3700 / \mathrm{mm}^{3}, \mathrm{CRP} 1.78 \mathrm{mg} / \mathrm{dl}$ と炎症反応は著明 に改善した (表 1)。甲状腺機能は軽度の立進を認め, サ 


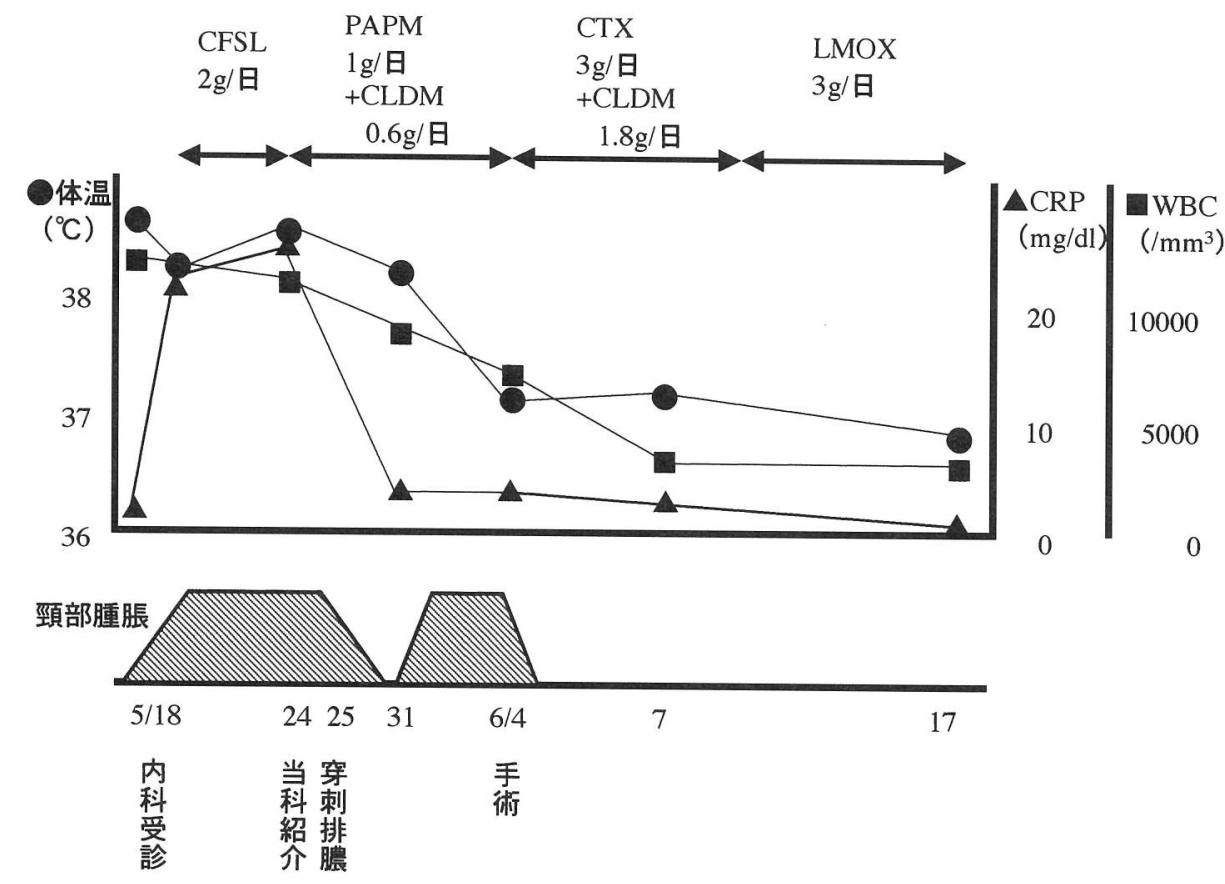

図 2 経過表

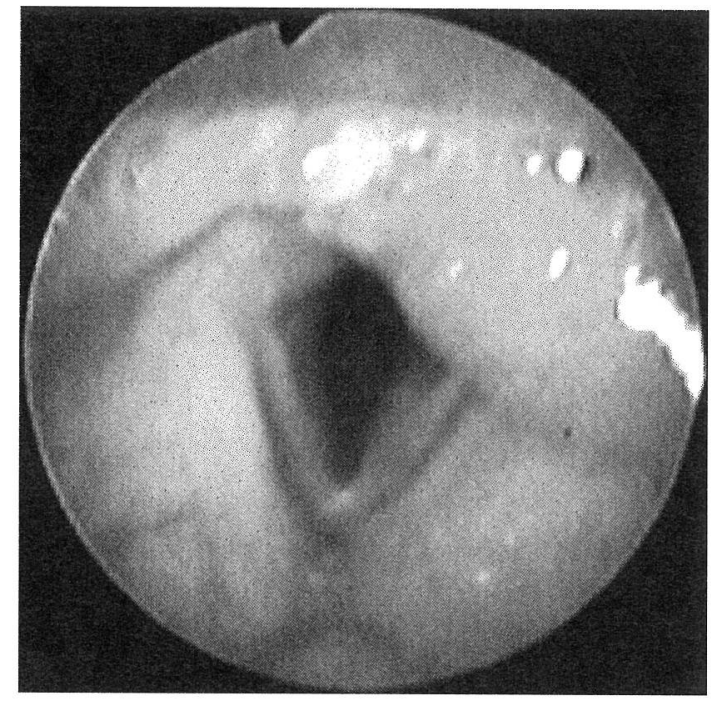

a

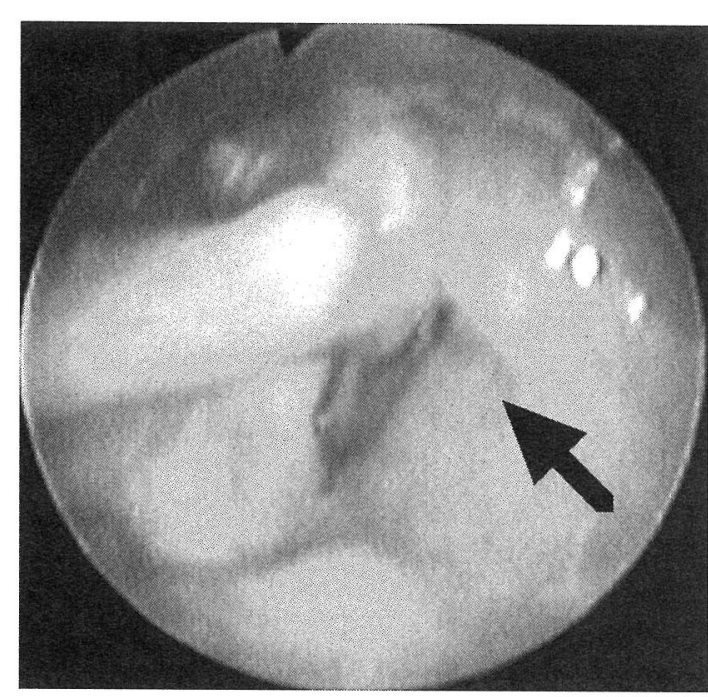

b

図 3 喉頭ファイバー所見

a. 吸気時：左の披裂部，仮声帯，声帯と声門下に浮腫を認め，左の梨状陥凹には唾液の貯留を認めた。

b. 発声時：左声帯の可動性は不良で，声門閉鎖は不十分である (矢印).

イロイドテスト，マイクロゾームテストは陰性であった (表 1)。6月11日からは耐性菌の発現を予防するために 菌検查で感受性のあったラタモキセフ (LMOX) $3 \mathrm{~g} /$ 日に
変更した (図 2)。6月 14 日には創部の菌検査は陰性と なった， 6 月 17 日には CRP が陰性化し，7月 1 日には甲 状腺機能も正常となった（表 1）ため，創部の自然閉鎖 


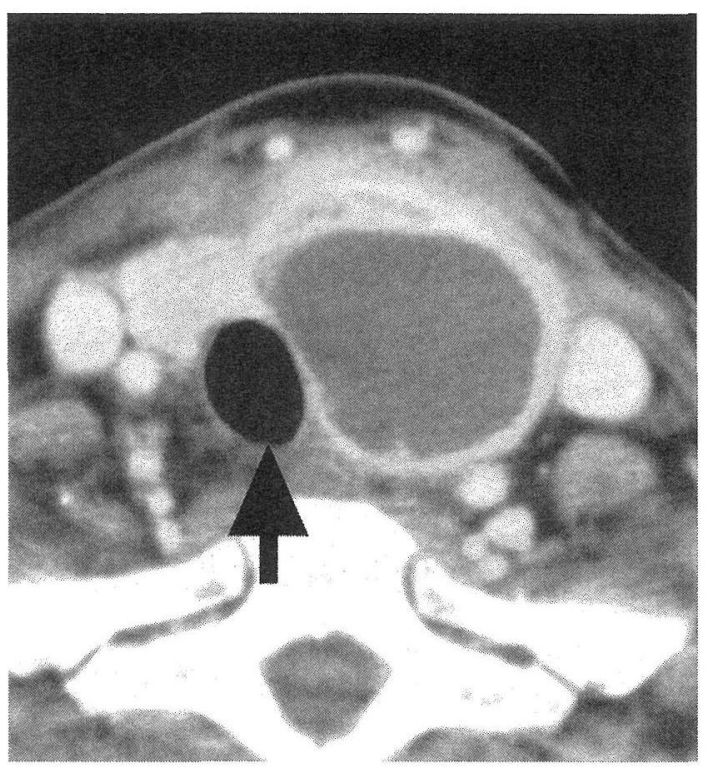

a

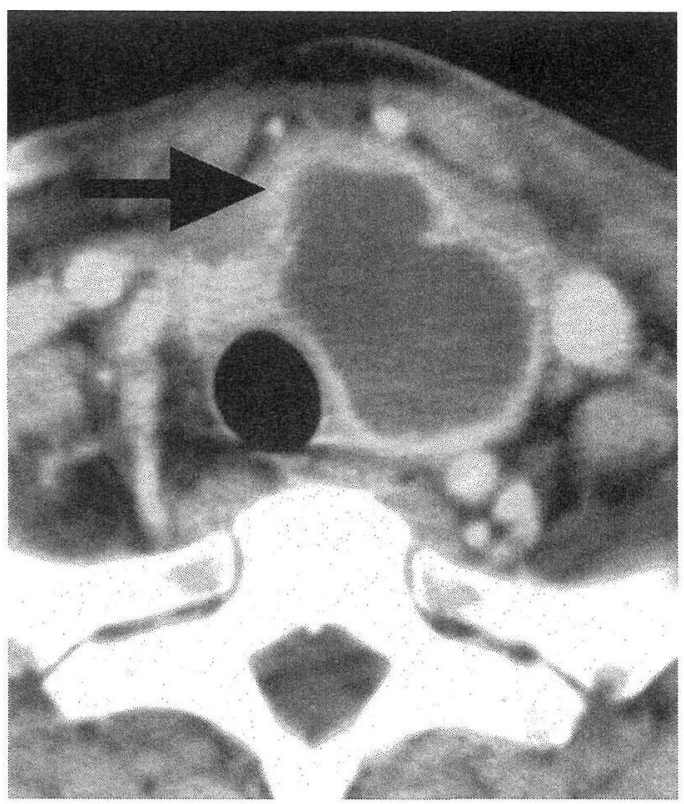

b

図 4 造影 CT 検查（a：5月 24 日, b : 5 月 31 日）

$\mathrm{a}$ ：甲状腺左葉下極に辺縁はやや不整で内部は右葉と比べ低吸収を示す均一な腫瘤状陰影を認める.気管は 著明に右方に圧排されている(矢印)。

$\mathrm{b}$ ：膿瘍腔は二房性で，前方への突出を認める（矢印）。

を待ち， 7 月 17 日退院となった。

7 月 22 日および 10 月 28 日に下咽頭食道造影を行った。 その際 Valsalva 手技も行ったが，いずれも下咽頭梨状陥 凹に瘦孔を示唆する所見は認めなかった。

退院後, 約 5 カ月間経過観察を行ったが再発は認めて いない.

\section{考察}

1）起炎菌について

急性化膿性甲状腺炎の起炎菌は口腔や咽頭の常在菌で あるStreptococcus, Staphylococcus, Klebsiella などが多く4), サルモネラが検出されることはまれである。サルモネラ 感染症は胃腸障害, チフス性疾患, 保菌, 限局性炎の 4 つに分類され 5), 急性化膿性甲状腺炎は限局性炎に含ま れる。限局性炎の頻度はサルモネラ感染症の $7.4 \%$ に過 ぎず，そのうちの $23.8 \%$ が膿瘍である5

限局性炎では, サルモネラが経口的に体内侵入後, 胃 腸障害の部位から一過性に血中に入り, 抵抗力の減弱し た組織に移行し潜伏感染する6) とされている，潜伏感染 発生時の消化器症状は不顕性のことが多く, そのため感
染時期に関しても不明のことが多い5)。サルモネラの生 体内除菌は大部分を細胞性免疫が担当していると考元ら れており, 限局性炎の発症には感冒, ステロイド使用6) や HIV 感染 等の感染防御能の減退が関連するとされて いる. 自験例でも下痢などの明らかな消化器症状は認め なかったが, 感冒罹患後より前頸部腫脹や疼痛が出現し ていた。

限局性炎を生じる部位は虫垂や胆囊なざ消化管と関連 した部位が多く, 甲状腺のように消化管と関連のない部 位に生じることはまれ8) とされている。われわ独医学 中央雑誌を用いて 1987 年以降 2002 年までの本邦文献を 涉猟した限りではサルモネラによる急性化膿性甲状腺炎 （以下, サルモネラ症例と略す）の報告はなかった. 英文 文献については Medline を用いて 1966 年以降 2000 年ま で渉猟したところ 31 例7) 30) の報告しか確認されなかっ た。これら 31 例中, 血清型が確認できた症例は 20 例あ り S. Typhi が 10 例, S. Enteritidis が 6 例, S. Brandenburg, S. Paratyphi A, S. Cholerae, S. Panama が各 1 例ずつで, 自 験例で検出された S. Anatum の報告はなかった。

2)感染経路について 
急性化膿性甲状腺炎の感染経路としては下咽頭梨状陥 凹瘦, リンパ行性, 周囲組織からの直接的波及, 甲状舌 管の遺残，外傷や血行性など3) がある. なかでも下咽頭 梨状陥凹瘦は 1979 年 Takai ら ${ }^{1)}$ が提言して以来注目され るようになり, 現在では主たる感染経路と考えられて (る ${ }^{2)}$ ．小林ら ${ }^{31)}$ は急性化膿性甲状腺炎 63 例中 53 例 (84. 1\%)で下咽頭梨状陥凹瘦が証明されたと報告してい る. 下咽頭梨状陥凹瘦以外では前述した経路が考えられ， 敗血症患者に起こった化膿性甲状腺炎の報告 32 ) や甲状舌 管を通じての感染の報告 ${ }^{33)}$ があるが，このような経路で の感染は非常に少ない.

下咽頭梨状陥凹瘦の検索方法には内視鏡的検查と画像 検查がある ${ }^{2)}$. 前者の場合, ファイバースコピーを用い, 瘻管開口部が大きければ下咽頭梨状陥凹瘻を確認するこ とができる. 後者の場合, 下咽頭食道造影, CT, MRI や 超音波検查で検索がなされる. 下咽頭食道造影では梨状 陥凹先端に細い瘦管が描出される. CT, MRI や超音波検 查では膿瘍の状態や甲状腺との関係，瘦管の存在が確認 できる，下咽頭梨状陥凹瘻の検索方法には以上のような 検索方法があるが，確定診断には下咽頭食道造影が必要 である2). しかし下咽頭食道造影を行う場合, 炎症が十 分に治まっていないときには瘦孔内腔の狭小化により瘦 孔が証明できないことがある4). また 1 回の下咽頭食道 造影だけでは瘦孔がないとはいえず，繰り返し検索を行 ら必要がある4). そのため自験例では炎症の消退を待ち, 2回下咽頭食道造影を行ったが瘦孔は証明されなかった。

リンパ行性感染の場合にはまず咽頭や扁桃に感染し頸 部リンパ節炎を経て感染する ${ }^{34)}$ が，自験例では頸部リン パ節腫大は認めず，口腔内の細菌検查でもサルモネラは 検出されなかった。自験例では，理学的所見や画像所見 からも炎症は甲状腺が主体で周囲での炎症は認めなかっ た。 また甲状舌管の遺残や外傷の既往もなかった。

血行性感染の場合, 血液培養で菌が証明されれば血行 性感染が明らかになるが，自験例では血液培養は陰性で あった．しかし，血液培養を行った時点ではすでに抗生
剤の投与がなされていたため, 血行性感染の可能性は否 定できない. 前述のサルモネラ症例 31 例では 8 例のみで 血液培養がなされており，そのうち 3 例で血液中からサ ルモネラが検出されていた。一方, 検出されなかった 5 例では血液培養を行った時点ではすでに抗生剤の投与が なされていた，前述したサルモネラによる限局性炎の感 染経路も考慮し, 自験例では血行性感染の可能性が最も 高いと考えた。

3）サルモネラ症例と下咽頭梨状陥凹瘦による急性化 膿性甲状腺炎症例の比較

過去に報告のあったサルモネラ症例31例のうち詳細を 確認できた 13 例7) 19) と自験例を含めた計 14 例につい て年齢, 性別, 患側, 治療法と再発例を検討し, 宮内 ${ }^{35)}$ の下咽頭梨状陥凹瘦による急性化膿性甲状腺炎症例（以 下, 下咽頭梨状佇凹瘦症例と略す) 48例と比較した (表2). サルモネラ症例では発症年齢は 25 歳から 79 歳までで, 25 歳の 1 例を除けば 13 例すべてが 40 歳以上で平均年齢 は 54.1 歳であった. 下咽頭梨状陥凹瘦症例では, 発症年 齢は 11 月から 56 歳までで平均年齢は 12.0 歳であった。 サルモネラ症例の場合, 保菌者となった後免疫力の低下 などが誘因となり発症することが多い78) ため, 発症年 齢が高いと推察した。一方，下咽頭梨状陥凹㾇症例の場 合, 瘦孔は先天性のものであるため低年齢での発症が多 いとされている.

性別に関してはサルモネラ症例では男性 5 例, 女性 9 例で，下咽頭梨状陷凹瘻症例では男性 20 例，女性 28 例 で，両者ともに女性に多い傾向であった。

患側の記載のあったサルモネラ症例は, 詳細を確認で きた 13 例中 10 例7) 16) と自験例の計 11 例のみであっ た. 11 例中では右側に発生したものが 6 例と最も多く, 左側に発生したものが 3 例, 正中に発生したものが 2 例 であった。一方, 下咽頭梨状陥凹瘦症例では 48 例中 45 例が左側に発生しており, 残りの 3 例は右側に発生して いた。 下咽頭梨状陷凹瘦症例の場合, 胎生期における下 頸部器官の発生が非対称であり左側が遅れるため左側に

表 2 サルモネラ症例と下咽頭梨状陥凹瘻症例の比較

\begin{tabular}{lcccc}
\hline \hline & 発症年齢 & 性別 (男性 : 女性) & 患側 (左: 正中:右) & 再発 \\
\hline サルモネラ症例 & 54.1 歳 & $5: 9$ & $3: 2: 6$ & $0 / 14$ 例 \\
下咽頭梨状陥凹瘻症例 & 12.0 歳 & $20: 28$ & $45: 0: 3$ & $32 / 48$ 例
\end{tabular}

サルモネラ症例の年齢, 性別, 再発は詳細の確認できた13例と自験例の計14例について, 患側に関しては詳細の確認で きた 10 例と自験例の計 11 例について検討した。 下咽頭梨状陥凹瘦症例は宮内 ${ }^{35)} の 48$ 例を引用した。 
発生する症例が圧倒的に多い36) とされている.

治療に関して, サルモネラ症例では切開排膿を要した 自験の 1 例をのぞくと,ほかの 13 例は膿場の穿刺排膿と 抗生剤の経静脈投与で治癒している。下咽頭梨状陷凹瘦 症例では急性炎症の場合, 抗生剤の投与や切開排膿に よって比較的容易に炎症は消退し，炎症が十分に治まっ てから瘦孔摘出が行われる. 瘦孔が非常に細い症例では 肉芽により瘦孔が閉塞し自然治瘉することもあるが，抗 生剂の投与や切開排膿等の保存的治療のみでは再発をき たすことが多く, 瘦孔を完全に摘出すれば炎症が再発す ることはない．

治療経過をみるとサルモネラ症例では再発は 1 例もな かったが，下咽頭梨状陥凹瘻症例では 48 例中 32 例に再 発を認め, その回数は $1 \sim 12$ 回とさまざまで平均 2.7 回 であった。

\section{まとめ}

サルモネラによる急性化膿性甲状腺炎のまれな 1 例を 経験し報告した。自験例では下咽頭梨状陥凹㾇は証明さ れず，血行性感染の可能性が高いと考えた，文献的には 31 例の報告が確認できたが，このうち詳細を確認できた 13 例と自験例をあわせたサルモネラ症例 14 例について 検討したところ, 下咽頭梨状陥凹瘻症例と比べ発症が高 齢で，患側は右側が多かった。切開を要した自験例を除 くと全例穿刺排膿と抗生剂経静脈投与で治癒し, 再発も なかった。

本論文の要旨は, 第 62 回耳鼻咽喉科臨床学会（平成 12 年 7 月 7, 8 日, 福井市）において口演した.

\section{参考文献}

1) Takai S, Miyauchi A, Matsuzuka F, et al. : Internal fistula as a route of infection in acute suppurative thyroiditis. Lancet 1 : $751 \sim 752,1979$.

2）山田洋一郎, 木田亮紀, 末野康平: 下咽頭梨状陥凹瘻. JOHNS $15: 877 \sim 880,1999$.

3) Hazard JB : Thyroiditis; a review. Am J Pathol 25:289 298, 1955.

4）小松博史, 上野たまき, 廣田隆一, 他：3 回目の咽頭食道 造影にて咽頭梨状窩瘦の存在を証明し得た急性化膿性甲状 腺炎の 1 例. 小児科臨床 $51: 979 \sim 982,1998$.

5) Saphra I and Winter JW : Clinical manifestations of salmonellosis in man; an evaluation of 7779 human infections identified at the New York Salmonella Center. N Engl J Med $256: 1128$ 1134, 1957.

6）西山政孝, 谷松智子, 宮田ひとみ, 他: Salmonella Enteritidis による化膿性関節炎の 1 症例. 愛媛県臨床検查技師会誌 31 : $42 \sim 46,1997$.

7) Lecuit M, Caumes E, Bricaire F, et al. : Acute suppurative Salmonella enteritidis thyroiditis associated with thyrotoxicosis in a patient infected with the human immunodeficiency virus. Clin Infect Dis $20: 196,1995$.

8) Svenungsson B and Lindberg AA : Acute suppurative salmonella thyroiditis; clinical course and antibody response. Scand J Infect Dis $13: 303 \sim 306,1981$.

9) Suskovic $T$ and Vucicevic $Z$ : Acute suppurative thyroiditis caused by Salmonella enteritidis. Infection $23: 180 \sim 181$, 1995.

10) Chiovato L, Canale G, Maccherini D, et al. : Salmonella brandenburg; a novel cause of acute suppurative thyroiditis. Acta Endocrinol 128: $439 \sim 442,1993$.

11) Fule RP and Saoji AM : Isolation of Salmonella paratyphi A from thyroid abscess; a case report. Indian J Med Sci 43:95 96, 1989.

12) Negi SC, Gupta MK, Goyal A, et al. : A case of Salmonella thyroiditis; an unusual manifestation of salmonellosis. Indian J Pathol Microbiol $27: 295 \sim 298,1984$.

13) Walter RM Jr and McMonagle JR : Salmonella thyroiditis, apathetic thyrotoxicosis, and follicular carcinoma in a Laotian woman. Cancer $50: 2493 \sim 2495,1982$.

14) Conrad C : Ultrasonography of the thyroid; an intracytic carcinoma and mouse typhoid induced abscess. Eur J Radiol 5 : 218 $\sim 220,1985$.

15) Igler $C$, Zahn $T$ and Muller $D$ : Thyroid abscess caused by Salmonella enteritidis. Dtsch Med Wochenschr $116: 695 \sim 698$, 1991.

16) Gudipati $S$ and Westblom TU : Salmonellosis initially seen as a thyroid abscess. Head Neck $13: 153 \sim$ 155, 1991.

17) Christensen J, Korner B and Karkov J : Salmonella abscesses. Ugeskr Laeger $147: 3483 \sim$ 3485, 1985.

18) Zimmermann CW, Lingenfelser $T$, Melms A, et al. : Abscess of the thyroid gland caused by Salmonella enteritidis in immunosuppressive treatment of generalized myasthenia gravis with thymoma. Nervenarzt $61: 626 \sim 628,1990$.

19) Jasmi AY, Rohaizak, Meah FA, et al. : Typhoid thyroiditis. Med J Malaysia $53: 109 \sim 111,1998$.

20) Olszynska $M$ and Jedynasty $\mathrm{K}: 2$ case of abscesses caused by Salmonella typhimurium. Wiad Lek $37: 1635 \sim$ 1639, 1984.

21) Koshi $G$ : Uncommon manifestations of salmonella infections. Indian J Med Res $64: 314 \sim 321,1976$.

22) Christie AB : Food Poisoning, Salmonellosis. Infectious Dis- 
eases; Epidemiology and Clinical Practice 2nd ed (ed by Christie AB). pp $3 \sim 54$, Churchill Livingstone, Edinburgh, 1974.

23) VanHeerden JA, O'Connell P : Acute suppurative thyroiditis due to Salmonella enteritidis. Va Med Mon $98: 556 \sim 557$, 1971.

24) Brenzier AG : Suppurative strumitis caused by Salmonella typhosa. Ann Surg $133: 247 \sim 252,1951$.

25) Burhans EC : Acute thyroiditis. Surg Gynecol Obstet $47: 478$ $\sim 487,1928$.

26) Womack NA : Thyroiditis. Surgery $16: 770 \sim 782,1944$.

27) Nmdau PT : Infective thyroiditis in northern Nigeria; a fifteenyear study. East Afr Med J $66: 748 \sim 751 ， 1989$.

28) Irmer W, Sommer T and Ulatowski L : Salmonella abscesses of the thyroid gland. Med Welt $27: 2469 \sim 2470,1976$.

29) Duraker N, Agac E and Ozpacaci T : Thyroid abscess caused by Salmonella typhi leading to vocal cord paralysis. Eur J Surg $166: 971 \sim 973,2000$.

30) Lalitha MK and John R : Unusual manifestations of salmonellosis; a surgical problem. Q J Med $87: 301 \sim 309,1994$.

31）小林健夫，竹村喜弘：29歳で初発した急性化膿性甲状腺炎
の一例と本邦 112 例の文献的考察. 総合臨床 $7: 2304 \sim$ 2308, 1992

32) Hawbaker EL : Thyroid abscess. Am Surg $37: 290 \sim 292$, 1971.

33) Saito $\mathrm{S}$ and Katakai $\mathrm{S}$ : Three cases of acute suppurative thyroiditis. Gunma J Med Sci 13 : 61， 1964.

34) Rosenberg RA, Liu PG and Myssiorek DJ : Cervical abscess caused by Salmonella infection. Am J Otolaryngol 6:42 45, 1985.

35）宮内 昭：急性化膿性甲状腺炎. 最新内科学大系第 13 巻 (井村裕夫編). $217 \sim 223$ 頁, 中山書店, 東京, 1993 .

36）阿部和男，藤田仁子，松浦信夫，他：急性化膿性甲状腺炎 の感染経路としての第 4 鰓囊性咽頭梨状窩瘻について. 日 児誌 $85: 44 \sim 47,1981$

原稿受付：平成15年 1 月 8 日 原稿採択：平成15年 2 月 26 日 別刷請求先：盛實 勲

于790-0923 松山市北久米町1059-2

リヴィエールA202 